\title{
Aggregates reduce transport distance of soil organic carbon: are our balances correct?
}

\author{
Y. Hu and N. J. Kuhn
}

Physical Geography and Environmental Change Research Group, Department of Environmental Sciences, University of Basel, Klingelbergstrasse 27, 4056 Basel, Switzerland

Correspondence to: Y. Hu (yaxian.hu@unibas.ch)

Received: 24 March 2014 - Published in Biogeosciences Discuss.: 12 June 2014

Revised: 24 September 2014 - Accepted: 9 October 2014 - Published: 17 November 2014

\begin{abstract}
The effect of soil erosion on global carbon cycling, especially as a source or sink for greenhouse gases, has been the subject of intense debate. The controversy arises mostly from the lack of information on the fate of eroded soil organic carbon (SOC) whilst in-transit from the site of erosion to the site of longer-term deposition. Solving this controversy requires an improved understanding of the transport distance of eroded SOC, which is principally related to the settling velocity of sediment fractions that carry the eroded SOC. Although settling velocity has already been included in some erosion models, it is often based on mineral particle size distribution. For aggregated soils, settling velocities are affected by their actual aggregate size rather than by mineral particle size distribution. Aggregate stability is, in turn, strongly influenced by SOC. In order to identify the effect of aggregation of source soil on the transport distance of eroded SOC, and its susceptibility to mineralization after transport and temporary deposition, a rainfall simulation was carried out on a silty loam. Both the eroded sediments and undisturbed soils were fractionated into six different size classes using a settling tube apparatus according to their settling velocities: $>250,125$ to 250,63 to 125,32 to 63,20 to 32 and $<20 \mu \mathrm{m}$. Weight, SOC content and instantaneous respiration rates were measured for each of the six class fractions. Our results indicate that (1) $41 \%$ of the eroded SOC was transported with coarse aggregates that would be likely re-deposited down eroding hillslopes, rather than with fine particles likely transferred to water courses; (2) erosion was prone to accelerate the mineralization of eroded SOC, and thus might contribute more $\mathrm{CO}_{2}$ to the atmosphere than current estimates which often ignore potential effects of aggregation; (3) preferential deposition of SOC-rich coarse aggre-
\end{abstract}

gates potentially causes an increase of SOC remaining in the colluvial system and a reduction of SOC flux to the alluvial or aquatic system. These findings identify a potential error of overestimating net erosion-induced carbon sink effects, and thus add an additional factor to consider when improving our current understanding of SOC erosion and deposition on hillslopes.

\section{Introduction}

The net effect of soil erosion as a source or sink of $\mathrm{CO}_{2}$ in the global carbon cycle has been the subject of intense debate (Lal, 2003; van Oost et al., 2007; Quinton et al., 2010; Dlugoß et al., 2012; Doetterl et al., 2012). On one hand, erosion exposes the previously incorporated soil organic carbon (SOC), which may accelerate the mineralization of eroded SOC (Jacinthe et al., 2002, 2004; Kuhn, 2007; Mora et al., 2007; Lal and Pimentel, 2008). On the other hand, deposition limits the decomposition of SOC upon burial, while input of decomposing plant material on the surface of eroding sites partially replaces the lost SOC (Harden et al., 1999; van Oost et al., 2007; Wang et al., 2010). So far, effects of erosion on $\mathrm{CO}_{2}$ emissions have mostly been assessed by comparing SOC stocks at the assumed site of erosion and the site of colluvial deposition (Stallard, 1998; Berhe, 2012; van Hemelryck et al., 2011; Nadeu et al., 2012; van Oost et al., 2012). One underlying assumption associated with this approach is that the redistribution of eroded SOC across landscapes is non-selective. However, several recent publications showed (at least) temporary enrichment of SOC in sediment, as well as preferential deposition of aggregates with size distribution 
Table 1. Mineral particle size distribution, soil organic carbon (SOC) distribution across mineral particle size, average SOC of bulk soil, and the percentage of stable aggregates greater than $250 \mu \mathrm{m}$ in the silty loam used in this study.

\begin{tabular}{|c|c|c|c|c|c|c|c|}
\hline & \multicolumn{5}{|c|}{ Mineral particle size $(\mu \mathrm{m})$} & \multirow{2}{*}{$\begin{array}{r}\text { SOC of original } \\
\text { soil }\left(\mathrm{g} \mathrm{kg}^{-1}\right)\end{array}$} & \multirow{2}{*}{$\begin{array}{l}\text { Aggregates greater } \\
\text { than } 250 \mu \mathrm{m}(\%)\end{array}$} \\
\hline & $<32$ & $32-63$ & $63-125$ & $125-250$ & $>250$ & & \\
\hline Weight $(\%)$ & $62.0 \pm 0.3$ & $29.1 \pm 0.4$ & $6.6 \pm 0.3$ & $1.2 \pm 0.1$ & $1.1 \pm 0.1$ & & \\
\hline $\mathrm{SOC}\left(\mathrm{g} \mathrm{kg}^{-1}\right)$ & $13.7 \pm 0.7$ & $3.0 \pm 0.3$ & $8.9 \pm 2.6$ & $21.9 \pm 0.8^{\mathrm{a}}$ & $26.4 \pm 1.3^{\mathrm{a}}$ & $10.8 \pm 0.4$ & $67.2 \pm 6.9$ \\
\hline $\begin{array}{l}\text { SOC mass } \\
\text { Proportion (\%) }\end{array}$ & 80.8 & 8.3 & 5.6 & 2.5 & 2.8 & & \\
\hline
\end{tabular}

a It might be overestimated due to the mixture of minute amount of residue or straw, which was previously incorporated into the aggregates but then released by dispersion and blended with coarse particles. Lowercase numbers indicate the range of minimum and maximum values $(n=3)$.

and SOC content that differ from original soils (Schiettecatte et al., 2008; Kuhn et al., 2009; Hu et al., 2013a; Kuhn, 2013). As a consequence, carbon balances drawn only from the SOC stocks on sites of erosion and colluvial deposition may not adequately consider the potential SOC re-deposition into the terrestrial system.

Regardless of selective or non-selective erosion, sediment fractions are all likely to experience preferential deposition. Therefore, SOC redistribution, either after selective or nonselective erosion, strongly depends on the transport distance of eroded aggregates. This is thus related to the respective settling velocities of sediment fractions carrying the eroded SOC (Dietrich, 1982; Kinnell, 2001, 2005). Although settling velocity has already been included in some erosion models, it is often based on mineral particle size distribution (Morgan et al., 1998; Beuselinck et al., 1999; Flanagan and Nearing, 2000; van Oost et al., 2004; Aksoy and Kavvas, 2005). But for aggregated soils, settling velocities are affected by the actual size, irregular shape, porosity of soil fractions and their incorporation with light-dense SOC (Kinnell and McLachlan, 1988; Loch, 2001; Hu et al., 2013b). In addition, the upper limits of the mineral particle size classes used in current erosion models are often smaller than the actual aggregate sizes. For instance, the largest class in van Oost et al. (2004) is only $90 \mu \mathrm{m}$, whereas up to $250 \mu \mathrm{m}$ for rill erosion in Morgan et al. (1998). Such limits may also skew the estimation on settling velocity of eroded sediment. Hence, mineral particle size classes, no matter how efficiently applicable in erosion models, are not the decisive factor that determines the actual settling behavior or movement of aggregates. Aggregation of original soil potentially increases the settling velocities of soil particles, thereby likely to reduce their transport distances after erosion (Hu et al., 2013b). This, in theory, would also reduce the transport distance of eroded SOC incorporated into soil aggregates.

The effect of aggregation of source soil may also affect the movement of SOC down eroding hillslopes. Aggregation is related to SOC content, and SOC is often increased in both macro- and micro-aggregates (Tisdall and Oades, 1982; Cambardella and Elliott, 1994). The quality and stabilizing mechanisms of SOC in the soil matrix also vary with dif- ferent aggregate conditions. For instance, physically stabilized SOC within macro- and micro-aggregates is protected by forming physical barriers between microbes and enzymes and their substrates, and thus very susceptible to mineralization after aggregates break up (Six et al., 2002). Chemically stabilized SOC results from the chemical or physicochemical binding between SOC and soil minerals (i.e., clay and silt particles). Such stabilization is also likely to be disturbed by aggregate breakup, as often occurs during erosion and transport (Starr et al., 2000; Lal and Pimentel, 2008; van Hemelryck et al., 2010). Biochemically stabilized SOC results from the inherent or acquired biochemical resistance to decomposition. Aggregate breakup might also affect the biodegradability of the SOC or the exposure to hydrolyzation. Therefore, erosion, either detaching aggregates from the soil matrix or disintegrating larger aggregates, may have diverse impacts on mineralization of eroded SOC (van Hemelryck et al., 2010; Fiener et al., 2012).

In this study, we aim to conduct an initial test of the theoretical deductions made above by fractionating eroded loess sediments, generated during a laboratory rainfall simulation, according to their settling velocities, and then measure their SOC content and instantaneous respiration rates.

\section{Materials and methods}

\subsection{Soil sampling and preparation}

A silty loam from the conventionally managed Bäumlihof Farm in Möhlin $\left(47^{\circ} 33^{\prime} \mathrm{N}, 7^{\circ} 50^{\prime} \mathrm{E}\right)$, near Basel in northwest Switzerland, was used in this study. The soil supports a maize-wheat-grass rotation. A-horizon material (top $20 \mathrm{~cm}$ ) was sampled from a gentle shoulder slope $(<5 \%)$ in March 2012. Previous research on the same silty loam showed that aggregation increased the settling velocity of original soil fractions, particularly the medium-sized fractions, in comparison with that expected based on the texture of the original soil ( $\mathrm{Hu}$ et al., 2013b). The mineral particle specific SOC distribution, average SOC content (LECO RC 612 at $550^{\circ} \mathrm{C}$ ), and aggregate stability of original soil (method adapted from Nimmo and Perkins, 2002) 
are shown in Table 1. The mineral particle size distribution was fractionated by wet-sieving, after dispersion by ultrasound using a Sonifier Model 250 from Branson, USA. The energy dissipated in the water/soil suspension was $60 \mathrm{~J} \mathrm{ml}^{-1}$ (i.e., energy $=$ output power $70 \mathrm{~W} \times$ time $85 \mathrm{~s} /$ suspension volume $100 \mathrm{ml})$. The SOC mass proportions across mineral particle size classes were calculated only from average values of individual weight and SOC content. Although the ultrasound energy used in $\mathrm{Hu}$ et al. (2013b) was not enough to thoroughly disperse the original soil into real mineral particles (Kaiser et al., 2012), such extent of dispersion was notable enough to demonstrate the potential underestimation of applying mineral particle size distribution to predict the settling velocity of eroded SOC. Hence, it is speculated that similar increasing effects would also occur to sediment fractions, and thus make the silty loam suitable to investigate the potential effects of aggregation of original soil on the transport distances of differently sized sediment fractions. While this study investigated only one soil, similar loess soils cover about $10 \%$ (ca. 14.9 million $\mathrm{km}^{2}$ ) of the global land area (Sartori, 2000). This study was thus considered relevant as it generally reflects the erodible nature of similar loess soils under similar management regimes. In the future, more experiments with soils of different aggregation and various SOC contents have to be carried out to expand our knowledge on the effects of aggregation to a wider range of soils.

\subsection{Experimental setup}

\subsubsection{Rainfall simulation}

The experiments consisted of three separate components: (1) rainfall simulation to sufficiently destroy aggregates, so as to ensure that the eroded sediments were less likely to experience further breakdown during the subsequent settling velocity measurements; (2) fractionation of the eroded sediments by a settling tube apparatus into six settling velocity classes; and (3) measurements of the instantaneous respiration rates of each settling class. The experiments were repeated three times in order to generate reliable erosion and respiration data.

Soils $(0-5 \mathrm{~cm}$ depth) were placed in a $150 \times 80 \mathrm{~cm}$ flume, which was pitched at a $15 \%$ gradient (Fig. 1a). Preliminary tests revealed that a flume of this size could generate sufficient runoff to initiate non-selective erosion on this particular silt loam. The soil was sieved into aggregates of a diameter less than $10 \mathrm{~mm}$, and oversized clods were excluded in order to reduce variations in surface roughness, both within the flume and between replicates. Leveling the surface also ensured that large roughness elements, in particular depressions, did not inhibit movement of aggregates across the flume and thereby prevent selective deposition on the soil surface. To assist drainage, the base of the flume was perforated and covered with a fine cloth and a layer of sand (ca. $5 \mathrm{~cm}$ ). A FullJet nozzle of $1 / 4 \mathrm{HH} 14 \mathrm{WSQ}$, installed $1.8 \mathrm{~m}$
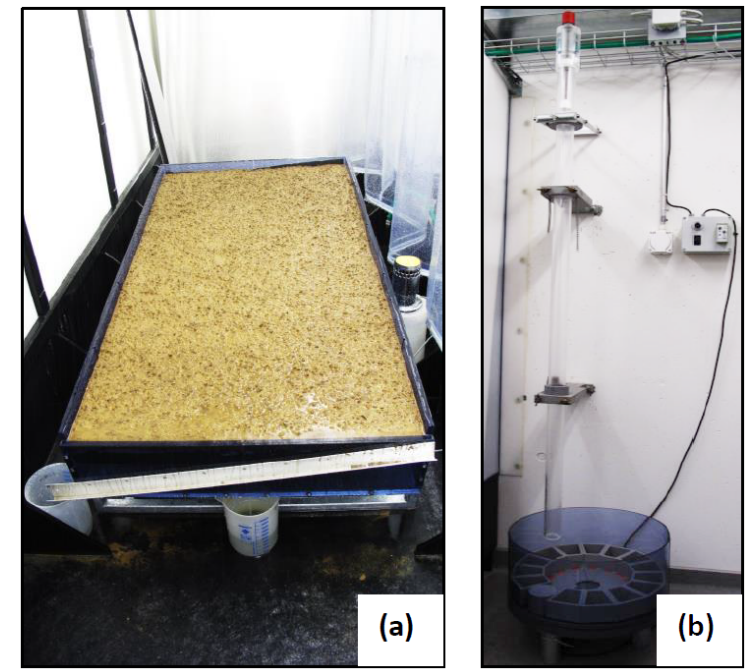

Figure 1. The rainfall simulation flume (a), and the settling tube apparatus (b). The settling tube apparatus consists of four components: the settling tube, through which the soil sample settles; the injection device, by which the soil sample is introduced into the tube; the turntable, within which the fractionated subsamples are collected; and the control panel, which allows an operator to control the rotational speed and rest intervals of the turntable (operations see $\mathrm{Hu}$ et al., 2013b).

above the soil surface, was used to generate rainfall. Soil of each replicate was then subjected to simulated rainfall at an intensity of $55 \mathrm{~mm} \mathrm{~h}^{-1}$ for $3 \mathrm{~h}$. The kinetic energy of the raindrops, detected by a Joss-Waldvogel disdrometer, was on average $200 \mathrm{~J} \mathrm{~m}^{-2} \mathrm{~h}^{-1}$.

Natural precipitation events of $55 \mathrm{~mm} \mathrm{~h}^{-1}$ are unlikely in the Möhlin region, where precipitation intensity is mostly less than $35 \mathrm{~mm} \mathrm{~h}^{-1}$ (return period of 0.33 years, MeteoSwiss, 2013). Increased intensity is often considered necessary to compensate for the deficiency of kinetic energy associated with simulated rainfall in order to recreate conditions that were as comparable as possible with natural rainfall (Dunkerley, 2008; Iserloh et al., 2012, 2013). A previous study had shown that full crust formation on the Möhlin silty loam (aggregates $<8 \mathrm{~mm}$ ) requires a cumulative kinetic energy of about $340 \mathrm{~J} \mathrm{~m}^{-2}$ (Hu et al., 2013a). This corresponds to natural precipitation of $35 \mathrm{~mm} \mathrm{~h}^{-1}$ for $30 \mathrm{~min}$ (Iserloh et al., 2012). Therefore, a simulated rainfall of $55 \mathrm{~mm} \mathrm{~h}^{-1}$ lasting for $3 \mathrm{~h}$ with a cumulative kinetic energy about $600 \mathrm{~J} \mathrm{~m}^{-2}$ was chosen in this study to make sure that the aggregates (coarser than those in Hu et al., 2013a) would experience full crust formation to equilibrium conditions; that is, resistance of crust against erosion equals the erosive force of raindrops and runoff.

Tap water, with an electric conductivity of $2220 \mu \mathrm{cm}^{-1}$, which is 5 times higher than natural rainwater in Basel, was used during each rainfall simulation. In general, the increased electric conductivity associated with tap water increases soil 
dispersion during tests using simulated rainfall (Borselli et al., 2001). Despite this, however, comparative aggregate stability tests showed only a $7 \%$ difference between rainwater sampled in Basel and ordinary tap water - thus making it acceptable.

\subsubsection{Sediment collection and fractionation by a settling tube apparatus}

During each rainfall event, runoff and sediment were continuously collected over $30 \mathrm{~min}$ intervals. A $1.8 \mathrm{~m}$ settling tube (Fig. 1b) was used to fractionate the eroded sediment fractions according to their respective settling velocities. The settling tube apparatus consists of four components (Fig. 1a): the settling tube, through which the soil sample settles; the injection device, by which the soil sample is introduced into the tube; the turntable, within which the fractionated subsamples are collected; and the control panel, which allows an operator to control the rotational speed and resting/moving intervals of the turntable. Details about the settling tube apparatus were described in Hu et al. (2013b). The injection device within this particular settling tube has a volume of $80 \mathrm{~cm}^{3}$. As this limits the amount of sediment used during each test, only sediment collected during the first 10 of each 30 min interval was used to determine settling velocities. In total, there were six sediment collection intervals over the $3 \mathrm{~h}$ rainfall events, and a settling fractionation test was carried for each of the six sediment collection intervals. Prior to being subjected to settling fractionation, the eroded sediment was allowed to settle for $1 \mathrm{~h}$ in collection beakers (height of $20 \mathrm{~cm}$ ). Measurements confirmed that $>95 \%$ of the total mass settled after this pretreatment. The supernatant and remaining suspended sediment (corresponding to EQS $<8 \mu \mathrm{m}$ ) was then decanted off and added to the $<20 \mu \mathrm{m}$ fraction remaining in suspension in the settling tube.

Six particle size classes, based on the concept of Equivalent Quartz Size (EQS) described in Hu et al. (2013b), were selected according to their likely transport distances after erosion (Table 2). EQS represents the diameter of a nominal spherical quartz particle that would fall with the same velocity as the aggregated particle for which fall velocity is measured (Loch, 2001). The six EQS classes were converted to six settling velocities and corresponding settling times using Stokes' law (Hu et al., 2013b). The use of Stokes' law to convert EQS into settling velocity is, in the strictest sense, limited to particles $<70 \mu \mathrm{m}$ (Rubey, 1933). From the perspective of terrestrial and aquatic systems, however, sediment fractions coarser than $63 \mu \mathrm{m}$ are considered as one group that is likely to be re-deposited along hillslopes. Therefore, the potential error when using Stokes' law to calculate the settling velocities of fractions of all sizes is considered acceptable. For soils dominated by larger mineral grains, different relationships should be used (Ferguson and Church, 2004; Wu and Wang, 2006). In addition, fine suspended fractions are considered as one group exported out of the terres-
Table 2. Six settling velocities based on the Equivalent Quartz Size (EQS) classes, and the likely fate of eroded fractions based on the conceptual model developed by Starr et al. (2000).

\begin{tabular}{lcl}
\hline EQS $(\mu \mathrm{m})$ & Settling velocity $\left(\mathrm{m} \mathrm{s}^{-1}\right)$ & Likely fate \\
\hline$<20$ & Suspension & Likely transferred to rivers \\
\hline $20-32$ & $3.3 \times 10^{-4}-1.0 \times 10^{-3}$ & \\
$32-63$ & $1.0 \times 10^{-3}-3.0 \times 10^{-3}$ & Possibly transferred to rivers \\
\hline $63-125$ & $3.0 \times 10^{-3}-1.5 \times 10^{-2}$ & \\
$125-250$ & $1.5 \times 10^{-2}-4.5 \times 10^{-2}$ & Deposited along eroding hillslopes \\
$>250$ & $>4.5 \times 10^{-2}$ & \\
\hline
\end{tabular}

trial system. Hence, with the current settling tube (length of $1.8 \mathrm{~m}$ ), any fractions finer than $20 \mu \mathrm{m}$ (settling time longer than $1.5 \mathrm{~h}$ ) were not further fractionated to save time. After fractionation, the six EQS classes were air-dried for $72 \mathrm{~h}$ in a dark environment at ambient temperature $\left(20^{\circ} \mathrm{C}\right)$. Despite the possibility of biasing the mineralization SOC potential through the process of air-drying, as the first step to unwrap the complex effects of aggregation onto SOC erosion, transport, and deposition, our aim was to produce quasinatural sediments, i.e., subjecting to a single rainfall event, successively re-deposited after increasing transport distances and immediately dried afterwards. Further effects of multiple rainfall events, other soil moisture conditions (e.g., wet sediments) and long-term incubation will be investigated in future research, once the role of aggregation on eroded SOC has been studied.

\subsubsection{Instantaneous respiration rate measurement}

Instantaneous respiration rates were measured, based on the method described in Robertson et al. (1999) and $\mathrm{Zi}$ bilske (1994). In brief, $2 \mathrm{~g}$ (dry weight) of each EQS size fraction were placed into a $30 \mathrm{~mL}$ vial and re-wetted using distilled water in order to obtain a gravimetric moisture content equivalent to ca. $60 \%$. Preliminary tests revealed that the gravimetric moisture of $60 \%$ represented a proper intermediate moisture level for sediment fractions of various surface areas, and thus exerted comparable effects on soil respiration rates (Xu et al., 2004; Bremenfeld et al., 2013). The re-wetting was done on the previous day before the respiration measurements. This way, the initial $\mathrm{CO}_{2}$ pulses of rewetted soils should be largely excluded (Orchard and Cook, 1983). Even if there were any $\mathrm{CO}_{2}$ pulses induced by rewetting, this exactly mimics the natural processes, where dry sediments deposited from previous rainfall events experience a second time of erosion and transport processes. All the re-wetted fractions were then incubated over night at $25^{\circ} \mathrm{C}$ (vials open). Two grams of original undisturbed soil were also prepared in the same way and used to generate reference measurements. Prior to soil respiration measurements, all vials were sealed using rubber stoppers. Gas from the headspace of each sealed vial was extracted by a $1 \mathrm{~cm}^{3}$ 
Table 3. Summary of the erosional responses of Möhlin soil over $180 \mathrm{~min}$ of rainfall time. Subscripted numbers indicate the minimum and maximum range of the parameters $(n=3)$.

\begin{tabular}{llllll}
\hline \multicolumn{9}{c}{ Steady state (after 120 min) } & & \\
\cline { 1 - 3 } $\begin{array}{l}\text { Runoff rate } \\
\left(\mathrm{mm} \mathrm{h}^{-1}\right)\end{array}$ & $\begin{array}{l}\text { Sediment discharge } \\
\text { rate }\left(\mathrm{g} \mathrm{m}^{-2} \mathrm{~h}^{-1}\right)\end{array}$ & $\begin{array}{l}\text { Sediment concentration } \\
\left(\mathrm{g} \mathrm{L}^{-1}\right)\end{array}$ & $\begin{array}{l}\text { Total runoff } \\
(\mathrm{kg})\end{array}$ & $\begin{array}{l}\text { Runoff coefficient } \\
(\%)\end{array}$ & $\begin{array}{l}\text { Total sediment } \\
\text { yield }(\mathrm{g})\end{array}$ \\
\hline $18.0 \pm 0.9$ & $168.7 \pm 14.4$ & $9.4 \pm 0.1$ & $40.7 \pm 3.1$ & $20.6 \pm 1.6$ & $475.8 \pm 74.6$ \\
\hline
\end{tabular}

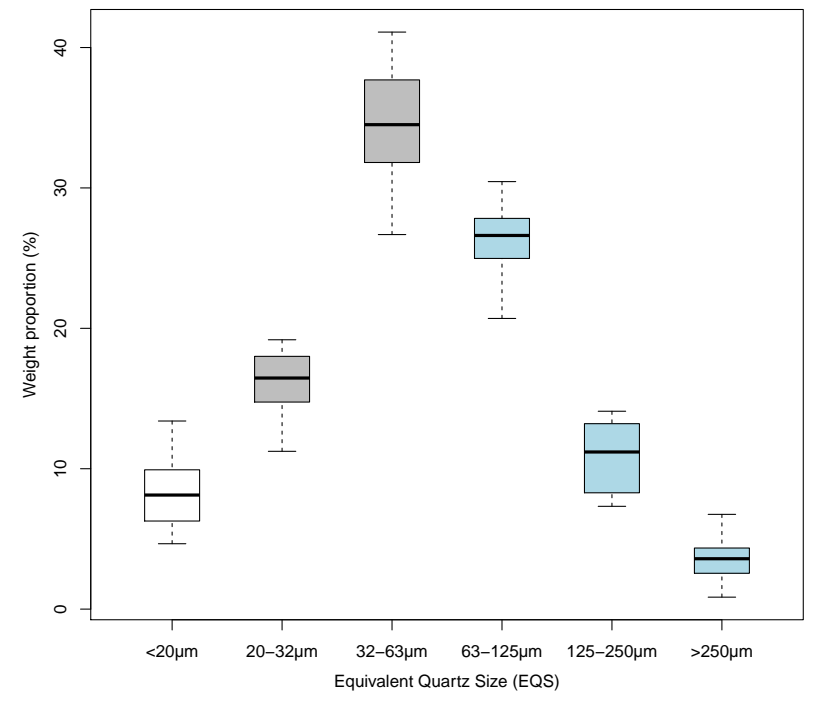

Figure 2. The weight distribution of different Equivalent Quartz Size (EQS) classes of the sediment. Colors of the boxes correspond to the likely fate of each fraction after erosion. See Sect. 4.1 and Fig. 6 for definitions and explanation of the three manners of likely fate. Bars in the boxes represent median values. Whiskers indicate the lowest datum within 1.5 interquartile range of the lower quartile, and the highest datum within 1.5 interquartile range of the upper quartile $(n=18)$.

syringe at the beginning and end of the $1 \mathrm{~h}$ sampling period. Differences in $\mathrm{CO}_{2}$ concentrations between these two measurements, as measured on a SRI8610C gas chromatograph, were used to calculate the instantaneous respiration rate.

\subsubsection{Laboratory measurements and data analyses}

Runoff samples collected during the late 20 of each $30 \mathrm{~min}$ interval were allowed to settle for more than $48 \mathrm{~h}$. The supernatant was then decanted off and the sediment was dried at $40^{\circ} \mathrm{C}$ and weighed. Soil erosion rates for each $30 \mathrm{~min}$ interval were estimated by the mass of sediment samples both from the beginning $10 \mathrm{~min}$ (sum of the six EQS classes) and the later $20 \mathrm{~min}$ (not fractionated by the settling tube). The SOC content of all the samples was measured by a LECO $\mathrm{RC} 612$ at $550{ }^{\circ} \mathrm{C}$. Data analysis was carried out using Microsoft Excel 2010 and R studio software packages (R version 2.15.1).
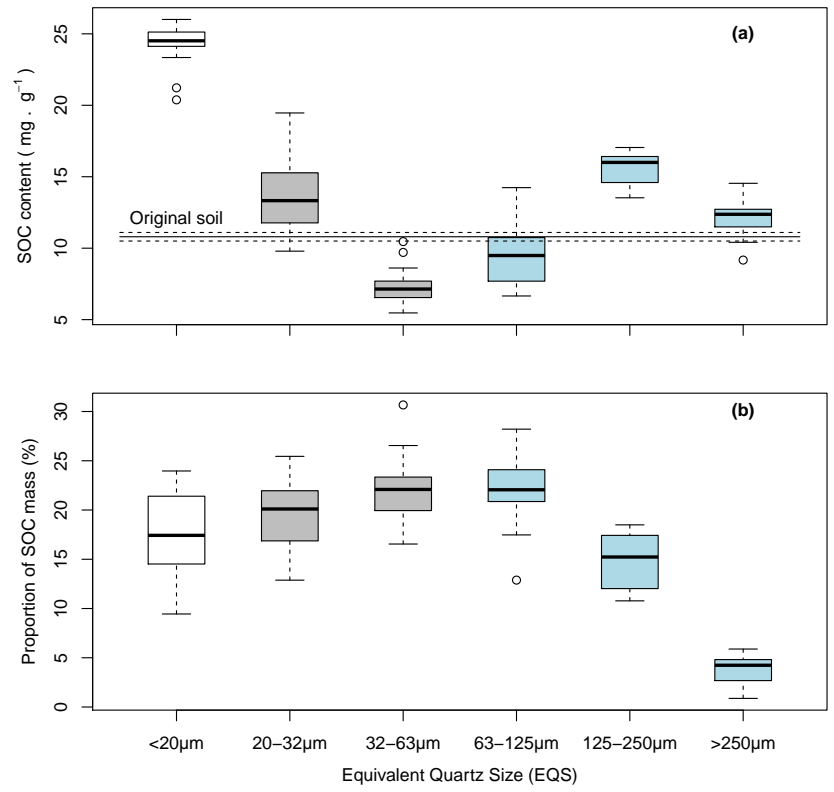

Figure 3. The distribution of soil organic carbon (SOC) content (a), and soil organic carbon (SOC) mass (b) in different Equivalent Quartz Size (EQS) classes of the sediment. The bold and dashed lines in (a) denote the average and standard deviation of soil organic carbon (SOC) content of the original soil. Colors of the boxes correspond to the likely fate of each fraction after erosion. See Sect. 4.1 and Fig. 6 for definitions and explanation of the three manners of likely fate. Bars in the boxes represent median values. Whiskers indicate the lowest datum within 1.5 interquartile range of the lower quartile, and the highest datum within 1.5 interquartile range of the upper quartile $(n=18)$.

\section{Results}

Runoff began after 20 min of rainfall and attained steadystate conditions equivalent to $18 \mathrm{~mm} \mathrm{~h}^{-1}$ after $120 \mathrm{~min}$. Sediment discharge rates followed a similar pattern and reached a steady state of $168.7 \mathrm{~g} \mathrm{~m}^{-2} \mathrm{~h}^{-1}$. Detailed erosional responses are listed in Table 3. During the simulated rainfall events, the sediments were seen to move continuously with runoff, and no evident selective deposition was observed on the soil surface.

The fraction mass and SOC in the six EQS classes of sediment are presented in Figs. 2 and 3. Preliminary data analysis had shown that while the absolute sediment mass increased 

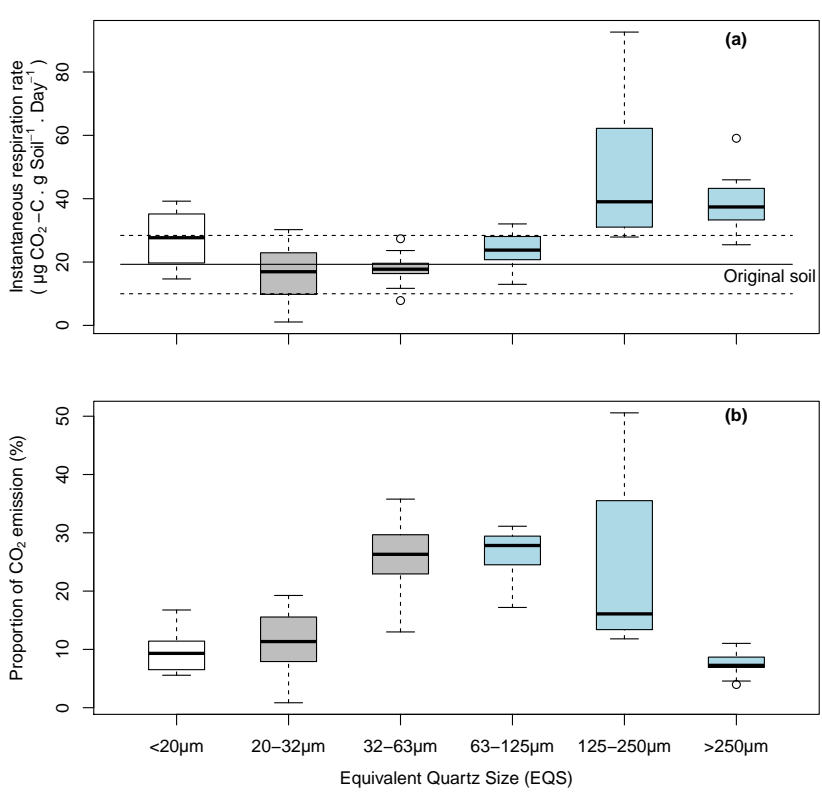

Figure 4. The distribution of instantaneous respiration rate (a); and potential $\mathrm{CO}_{2}$ emission (b) in different Equivalent Quartz Size (EQS) classes of the sediment. The bold and dashed lines in (a) denote the average and standard deviation of instantaneous respiration rate of the original soil. Colors of the boxes correspond to the likely fate of each fraction after erosion. See Sect. 4.1 and Fig. 6 for definitions and explanation of the three manners of likely fate. Bars in boxes represent median values. Whiskers indicate the lowest datum within 1.5 interquartile range of the lower quartile, and the highest datum within 1.5 interquartile range of the upper quartile $(n=18)$.

during the simulated rainfall events, the proportional composition of six EQS classes in each sediment collection interval did not differ significantly between samples (ANOVA, single factor, $P>0.05, n=18$ ). Hence, only proportional values are presented, and each EQS class could be considered to have 18 replicates (6 sediment collection intervals during each of the 3 rainfall events). Nevertheless, the distribution of fraction mass and SOC content considerably differed across six EQS classes: about $61 \%$ of the sediment fractions were in EQS of 32 to 63 and 63 to $125 \mu \mathrm{m}$, containing about $65 \%$ of the SOC. This SOC distribution in six EQS classes of sediment also contrasts the association of SOC with mineral particles in the original soil (Table 1).

The instantaneous respiration rates from EQS classes of 32 to 63 and 63 to $125 \mu \mathrm{m}$ were on average lower than those from other fractions (Fig. 4a). However, after multiplying the respiration rate from each class with its fraction mass (Fig. 2), EQS classes of 32 to 63 and 63 to $125 \mu \mathrm{m}$ on average released an even larger amount of $\mathrm{CO}_{2}$ than all other finer or coarser classes did (Fig. 4b). The instantaneous respiration rates per gram of SOC also differ among different EQS classes. In EQS classes $<20$ and 20 to $32 \mu \mathrm{m}$, the instantaneous respiration rates per gram of SOC were lower than those in the original soil (Fig. 5). In contrast,

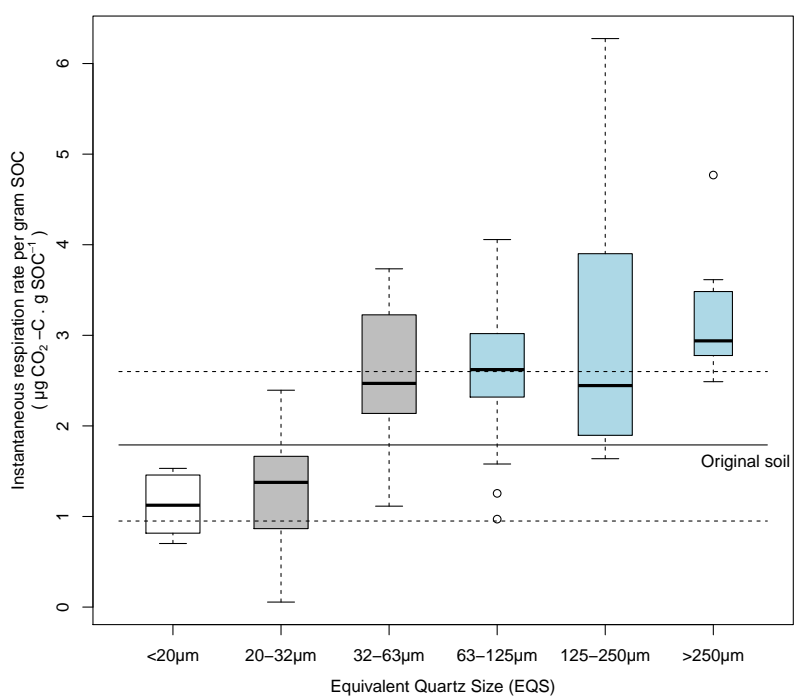

Figure 5. The distribution of instantaneous respiration rate per gram of soil organic carbon (SOC) in different Equivalent Quartz Size (EQS) classes of the sediment. The bold and dashed lines denote the average and standard deviation of instantaneous respiration rate per gram SOC of the original soil. Colors of the boxes correspond to the likely fate of each fraction after erosion. See Sect. 4.1 and Fig. 6 for definitions and explanation of the three manners of likely fate. Bars in boxes represent median values. Whiskers indicate the lowest datum within 1.5 interquartile range of the lower quartile, and the highest datum within 1.5 interquartile range of the upper quartile $(n=18)$.

all the other four EQS classes (> $32 \mu \mathrm{m}$ ) had higher instantaneous respiration rates per gram of SOC than the original soil (Fig. 5). We attribute the increased respiration rates per gram of SOC in EQS classes $>32 \mu \mathrm{m}$ to the detachment and transport of eroded soils, during which time the structural aggregates were broken down, thereby exposing the previously protected SOC to microbial processes (Six et al., 2002; Lal and Pimentel, 2008; van Hemelryck et al., 2010).

\section{Discussion}

\subsection{Likely fate of eroded SOC in the terrestrial and aquatic system}

Fractionation of eroded sediment by settling velocity shows that aggregation of source soil has a clear potential to affect the movement of sediment fractions and thus the fate of the associated SOC after erosion. According to the conceptual model developed by Starr et al. (2000) (Fig. 6), the six EQS classes can be further grouped into three separate groups, each with a different likely fate: $\mathrm{EQS}<20 \mu \mathrm{m}$ would be likely to remain suspended in runoff and, hence, transferred to rivers, and all EQS $>63 \mu \mathrm{m}$ would be re-deposited along eroding hillslopes (Table 2). The intermediate EQS of 20 to 32 and 32 to $63 \mu \mathrm{m}$ can have either fate, depending 


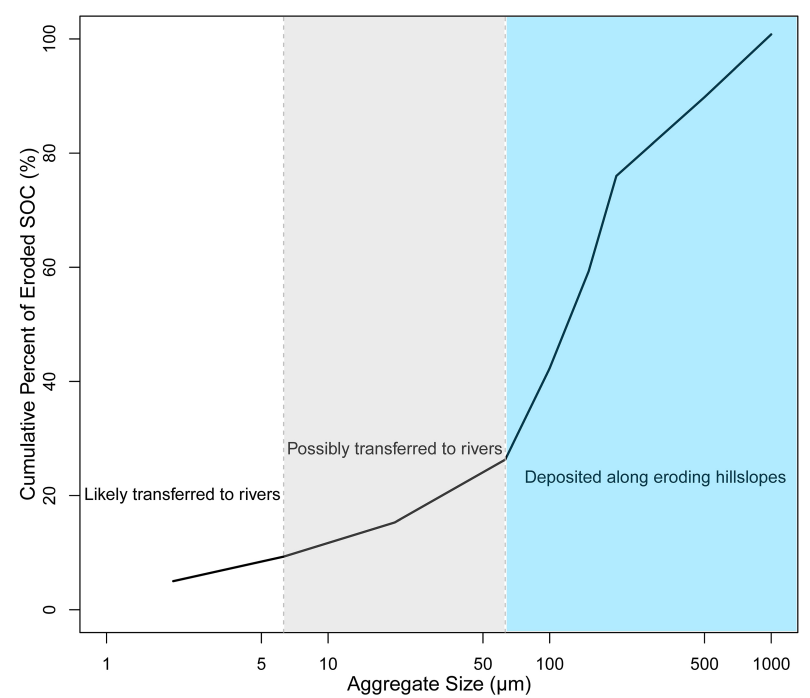

Figure 6. Likely fate of eroded soil organic carbon (SOC) as a function of aggregate size, re-drawn from the conceptual model developed by Starr et al. (2000). Blocks of different colors represent three manners of likely fate of eroded SOC, divided by the two convenient cutoff points: aggregate size of 6.3 and $63 \mu \mathrm{m}$. See Sect. 4.1 for definitions and explanation of the three manners of likely fate.

on localized flow hydraulics. In accordance with this model, approximately $41 \%$ of the eroded SOC from the silt loam used in this study would be re-deposited along eroding hillslopes (Fig. 7b). This proportion strongly contrasts the approximately $11 \%$ SOC mass associated with coarse mineral particles $>63 \mu \mathrm{m}$ in the original soil (Table 1), and is also contrary to the high SOC content $\left(24.3 \mathrm{mg} \mathrm{g}^{-1}\right)$ in sediment fraction of EQS $<20 \mu \mathrm{m}$ (Fig. 3a). These results support our theoretical deduction that aggregation of source soil reduces the likely transport distance of eroded SOC. This would then decrease the likelihood of eroded SOC being transferred from eroding hillslopes to aquatic systems, but increase the amount of eroded SOC being re-deposited into terrestrial systems. These findings are consistent with those reported by $\mathrm{Hu}$ et al. (2013b), in which $79 \%$ of the eroded SOC mass in a silty loam was associated with mineral particles of size $<32 \mu \mathrm{m}$, whereas $73 \%$ of the SOC mass was actually contained in aggregates of EQS $>63 \mu \mathrm{m}$. The distinct SOC distribution across aggregate size classes also agrees with the field investigation by Polyakov and Lal (2008), where the coarse aggregates ( 1 to $0.5 \mathrm{~mm}$ ) fractionated by wet-sieving, contained up to 4.5 times more SOC than the finest fraction $(<0.05 \mathrm{~mm})$. More experiments are required to describe the effects of different aggregation degrees and SOC contents.

\subsection{Erosion as a source of $\mathrm{CO}_{2}$ flux}

The effect of aggregation on the likely fate of SOC may also cast new light on understanding the effect of soil erosion on global carbon cycling. Based on the EQS specific
SOC content (Fig. 3), the potential SOC stock of a nominal $25 \mathrm{~cm}$ layer of topsoil on the foot slope of a colluvial depositional site, assumingly composed of aggregates EQS $>63 \mu \mathrm{m}$, would be $5.1 \mathrm{~kg} \mathrm{~m}^{-2}$ on average (Table 4). The potential SOC stock from the same $25 \mathrm{~cm}$ layer of original soil would be only $4.5 \mathrm{~kg} \mathrm{~m}^{-2}$, or $15.5 \%$ lower than that on the foot slope of a colluvial depositional site. Such a large difference implies that a combined model approach (Eq. 1), integrating the effects of aggregation on the likely fate of $\mathrm{SOC}$, is demanded to adequately distinguish the proportion of SOC likely re-deposited along hillslopes from the portion of potentially transferred to aquatic systems.

$S_{\mathrm{d}} \cdot \mathrm{C}_{\mathrm{d}}=S_{\mathrm{e}} \cdot \mathrm{C}_{\mathrm{e}}-S_{\mathrm{a}} \cdot \mathrm{C}_{\mathrm{a}}-\mathrm{C}_{\min }$,

where $S_{\mathrm{d}}$ is the mass of sediment likely to be re-deposited along hillslopes; $\mathrm{C}_{\mathrm{d}}$ is the carbon content of sediment likely to be re-deposited along hillslopes; $S_{\mathrm{e}}$ is the mass of eroded soil; $\mathrm{C}_{\mathrm{e}}$ is the carbon content of eroded soil; $S_{\mathrm{a}}$ is the mass of sediment potentially to be transferred to aquatic systems; $\mathrm{C}_{\mathrm{a}}$ is the carbon content of sediment potentially to be transferred to aquatic systems; $\mathrm{C}_{\min }$ is the carbon mineralized during transport.

In previous reports, $\mathrm{C}_{\min }$ was considered to be a minor constituent in the overall carbon budget, and $\mathrm{C}_{\mathrm{d}}$ was often assumed equivalent to the average of $\mathrm{C}_{\mathrm{e}}$ (Stallard, 1998; Harden et al., 1999; Berhe et al., 2007; van Oost et al., 2007; Quinton et al., 2010). However, if presuming that $C_{e}$ equals $\mathrm{C}_{\mathrm{d}}$ observed in topsoil of colluvial depositional sites (e.g., in van Oost et al., 2012), then the $C_{d}$ would lead to an overestimation of total SOC loss from eroding sites, because $C_{d}$ is likely enriched by SOC-rich aggregates compared to $\mathrm{C}_{\mathrm{e}}$ due to preferential deposition. Conversely, assuming $\mathrm{C}_{\mathrm{d}}$ corresponds to $\mathrm{C}_{\mathrm{e}}$ observed in topsoil at eroding sites (e.g., in Dlugoß et al., 2012) would neglect the potential enrichment of SOC in sediment fractions preferentially deposited on hillslopes. This would thus lead to an underestimation of $\mathrm{C}_{\mathrm{min}}$ during transport. In both cases, SOC transferred to aquatic systems would be overestimated. The observed enrichment of SOC by $15.5 \%$ in sediment fractions composed only of EQS $>63 \mu \mathrm{m}$ indicates that the potential error of abovedescribed estimates could be considerable. A $15.5 \%$ SOC enrichment of sediment re-deposited in the terrestrial system corresponds to the proportion of eroded SOC estimated to be deposited in permanent sinks (e.g., $0.12 \mathrm{Pg}$ of SOC eroded per year by van Oost et al. 2007). While the effects of aggregation on SOC redistribution and subsequent fate cannot be assessed based on one experiment, most sediment is transported in the form of aggregates (Walling, 1988; Walling and Webb, 1996). Ignoring the effect of aggregation on erosion and redistribution of SOC, therefore, bears the risk of overestimating the erosion-induced carbon sink effect. As a consequence, the behavior of aggregated sediment requires a reconsideration of existing approaches of sediment behavior in erosion models. Further study of different soil types, their aggregation and aggregate breakdown while moving across 

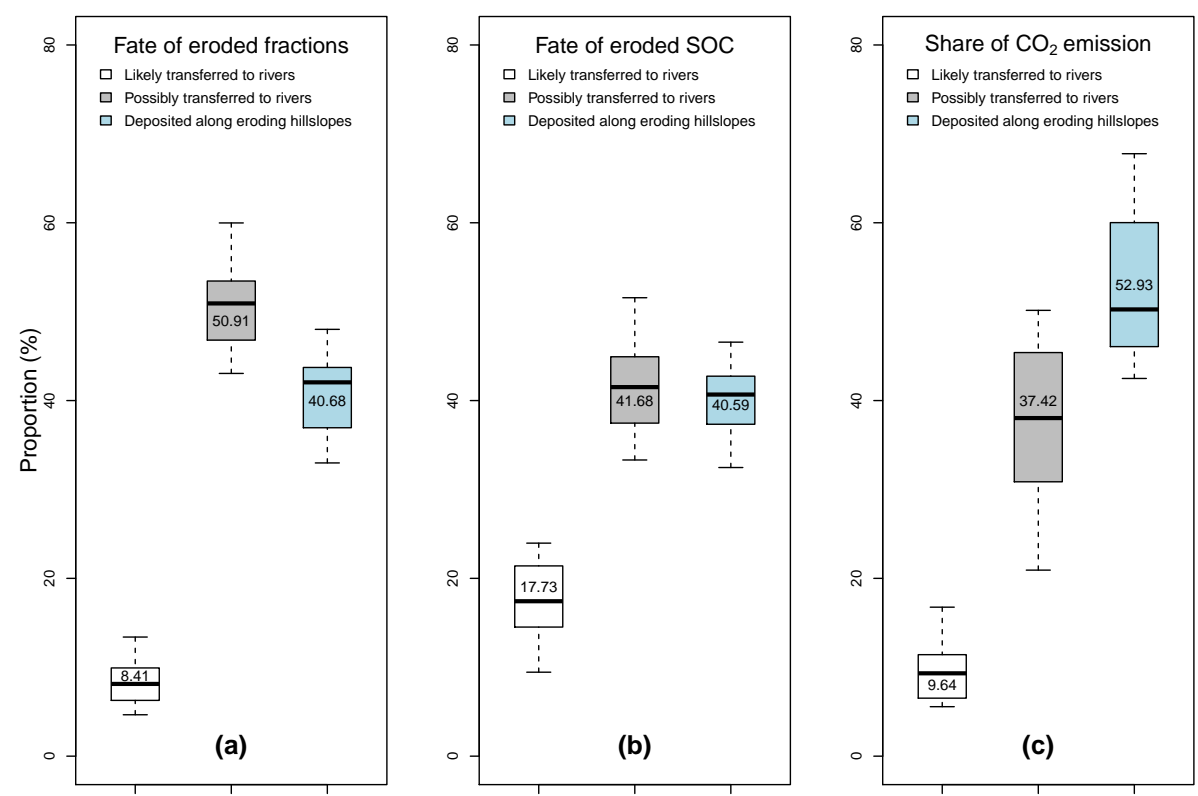

Figure 7. The likely fate of sediment fractions (a), eroded SOC (b), and potential share of $\mathrm{CO}_{2}$ emission (c) by fractions that would have been likely transferred to rivers, possibly transferred to rivers, and deposited along eroding hillslopes. The bar in box represents the median value, while numbers written in each box denote the average value. Whiskers indicate the lowest datum within 1.5 interquartile range of the lower quartile, and the highest datum within 1.5 interquartile range of the upper quartile $(n=18)$.

Table 4. Comparison between soil organic carbon (SOC) stock in top layer of $25 \mathrm{~cm}$ from a temporary depositional site which is theoretically composed of only three Equivalent Quartz Size (EQS) classes, and SOC stock of average original soil in the same top layer of $25 \mathrm{~cm}$ as often applied in previous literature.

\begin{tabular}{lrrrrrr}
\hline & EQS & $\begin{array}{r}\text { SOC content } \\
\left(\mathrm{mg} \mathrm{g}^{-1}\right)\end{array}$ & $\begin{array}{r}\text { SOC stock } \\
\left(\mathrm{kg} \mathrm{m}^{-2}\right)^{\mathrm{a}}\end{array}$ & $\begin{array}{r}\text { Differences } \\
(\%)^{\mathrm{b}}\end{array}$ & $\begin{array}{r}\text { Average SOC } \\
\text { stock }\left(\mathrm{kg} \mathrm{m}^{-2}\right)\end{array}$ & $\begin{array}{r}\text { Average } \\
\text { differences }(\%)^{\mathrm{b}}\end{array}$ \\
\hline \multirow{3}{*}{ Re-distributed fractions } & $>250$ & 12.2 & 5.0 & -11.1 & & \\
& $125-250$ & 15.7 & 6.5 & -44.4 & 5.1 & -15.5 \\
\hline Original soil & $63-125$ & 9.6 & 4.0 & +11.1 & & $\mathrm{NA}$ \\
\hline
\end{tabular}

${ }^{\text {a }}$ Accurate bulk densities for sediment fractions of different aggregate sizes are not available, so only particle density $1.65 \mathrm{~g} \mathrm{~cm}^{-3}$ is applied here to form a preliminary comparison.

${ }^{\mathrm{b}}$ Minus (-) means underestimation compared to the original soil; plus (+) means overestimation compared to the original soil.

landscapes of varying topography during rainfall events of different intensity, frequency and duration is required to assess the relevance of aggregation for SOC movement and fate identified in this study.

The risk of falsely estimating SOC losses during transport is further exacerbated by the observed instantaneous respiration rates. The instantaneous respiration rates probably merely represent a spike of SOC mineralization after erosion and, therefore, should not be extrapolated over longer periods of time. However, the $41 \%$ proportion of eroded SOC, which would likely be re-deposited along hillslopes, generated $53 \%$ of the entire instantaneous respiration (Fig. 7c). This implies that the immediately deposited SOC is more susceptible to mineralization than both the mass of coarse sediment fractions and their SOC content would suggest. These find- ings are consistent with those observed by van Hemelryck et al. (2010), who reported that a significant fraction of SOC eroded from initially dry soil aggregates is mineralized after deposition. As a consequence, the preferentially deposited SOC could potentially generate a further error in the carbon source-sink balance. Such an error would be particularly significant when repeated erosion and deposition processes along hillslopes cause further disintegration of large aggregates (Kuhn et al., 2003; van Hemelryck et al., 2010). This would thereby result in additional SOC exposure and mineralization (Jacinthe et al., 2002; Six et al., 2002). Overall, as a result of preferential deposition of SOC-enriched sediment fractions and enhanced mineralization during transport, the carbon losses during transport, so far assumed to be small 
(van Oost et al., 2007; Quinton et al., 2010), would actually be underestimated.

\section{Conclusions}

This study aimed to identify the effects of aggregation of source soil on the likely transport distance of eroded SOC and its susceptibility to mineralization after single-event transport and deposition. Our data show that $41 \%$ of the eroded SOC from a silty loam was incorporated into aggregates of EQS $>63 \mu \mathrm{m}$, and hence would likely be redeposited into the terrestrial system rather than being transferred to the aquatic system. This proportion is much greater than the approximately $11 \%$ SOC mass associated with coarse mineral particles $>63 \mu \mathrm{m}$ in the original soil (Table 1) and the high SOC content $\left(24.3 \mathrm{mg} \mathrm{g}^{-1}\right)$ in sediment fraction of EQS $<20 \mu \mathrm{m}$ would suggest. Respiration rates from sediment fractions of EQS $>63 \mu \mathrm{m}$ also increased immediately after erosion and deposition. Both results indicate that aggregation of source soil and preferential deposition of SOCrich coarse sediment fractions may skew the re-deposition of eroded SOC towards the terrestrial system, rather than further transfer to the alluvial or aquatic system. Consequently, a risk of overestimating lateral SOC transfer exists when mineral grain size rather than actual size of aggregated sediment is applied in erosion models. Our very limited data indicate that this error could be potentially within the same range as the current estimate of annual net erosion-induced carbon sink rate.

While based on a laboratory experiment and thus with very limited applicability to real landscapes, the potential effects of aggregation of source soil on reducing the transport distance of eroded SOC appear to be considerable. This illustrates the need to integrate the effect of aggregation of source soil on SOC transport distance into soil erosion models (e.g., as a soil erodibility parameter), in order to adequately distinguish SOC likely re-deposited in the terrestrial system from the portion potentially transferred to aquatic systems, and further assess the implications to the global carbon cycle. Further research should, therefore, focus on the effects of preferential deposition of eroded aggregates and the fate of SOC in these aggregates whilst in-transit and during multiple rainfall events. More simulations as well as field experiments are also needed to examine the effects of various transport processes (such as slope length, slope gradients, field barriers) onto the mechanism of aggregate breakdown and aggregate specific SOC distribution. The effects of varying rainfall characteristics, crust formation, soil management and topography (e.g., Wang et al., 2008; Hu et al., 2013a) onto SOC transport should also be investigated.

Acknowledgements. We gratefully acknowledge the financial support granted by Chinese Scholarship Council and the University of Basel, Switzerland. The contributions of Ruth Strunk and
Mathias Würsch in carrying out the laboratory experiments are also gratefully acknowledged. We particularly appreciate the generous support of Franz Conen with the respiration measurements. The draft of the manuscript was substantially improved by comments from Phil Greenwood and four anonymous reviewers. We would also like to remember Marianne Caroni, a member of the laboratory staff whose passing was much too premature and who is still sorely missed in the department.

Edited by: Y. Kuzyakov

\section{References}

Aksoy, H. and Kavvas, M. L.: A review of hillslope and watershed scale erosion and sediment transport models, Catena, 64, 247-271, doi:10.1016/j.catena.2005.08.008, 2005.

Berhe, A. A.: Decomposition of organic substrates at eroding vs. depositional landform positions, Plant Soil, 350, 261-280, doi:10.1007/s11104-011-0902-z, 2012.

Berhe, A. A., Harte, J., Harden, J. W., and Torn, M. S.: The significance of the erosion-induced terrestrial carbon sink, BioScience, 57, 337-346, 2007.

Beuselinck, L., Govers, G., Steegen, A., Hairsine, P. B., and Poesen, J.: Evaluation of the simple settling theory for predicting sediment deposition by overland flow, Earth Surf. Proc. Land., 24, 993-1007, 1999.

Borselli, L., Torri, D., Poesen, J., and Sanchis, P.: Effects of water quality on infiltration, runoff and interrill erosion processes during simulated rainfall, Earth Surf. Proc. Land., 26, 329-342, 2001.

Bremenfeld, S., Fiener, P., and Govers, G.: Effects of interrill erosion, soil crusting and soil aggregate breakdown on in situ $\mathrm{CO}_{2}$ effluxes, Catena, 104, 14-20, doi:10.1016/j.catena.2012.12.011, 2013.

Cambardella, C. A. and Elliott, E. T.: Carbon and nitrogen dynamics of soil organic matter fractions from cultivated grassland soils, Soil Sci. Soc. Am. J., 58, 123-130, 1994.

Dietrich, W. E.: Settling velocity of natural particles, Water Resour. Res., 18, 1615-1626, 1982.

Dlugoß, V., Fiener, P., Van Oost, K., and Schneider, K.: Model based analysis of lateral and vertical soil carbon fluxes induced by soil redistribution processes in a small agricultural catchment: Modelling Soil Redistribution \&amp; Soil Carbon Dynamics, Earth Surf. Proc. Land., 37, 193-208, doi:10.1002/esp.2246, 2012.

Doetterl, S., Six, J., Van Wesemael, B., and Van Oost, K.: Carbon cycling in eroding landscapes: geomorphic controls on soil organic $\mathrm{C}$ pool composition and $\mathrm{C}$ stabilization, Glob. Change Biol., 18, 2218-2232, doi:10.1111/j.1365-2486.2012.02680.x, 2012.

Dunkerley, D.: Rain event properties in nature and in rainfall simulation experiments: a comparative review with recommendations for increasingly systematic study and reporting, Hydrol. Process., 22, 4415-4435, doi:10.1002/hyp.7045, 2008.

Ferguson, R. I. and Church, M.: A Simple Universal Equation for Grain Settling Velocity, J. Sediment. Res., 74, 933-937, 2004.

Fiener, P., Dlugoß, V., Korres, W., and Schneider, K.: Spatial variability of soil respiration in a small agricultural watershed Are patterns of soil redistribution important?, Catena, 94, 3-16, doi:10.1016/j.catena.2011.05.014, 2012. 
Flanagan, D. C. and Nearing, M. A.: Sediment particle sorting on hillslope profiles in the WEPP model, Trans. ASAE, 43, 573-583, 2000.

Harden, J. W., Sharpe, J. M., Parton, W. J., Ojima, S., Fries, T. L., Huntington, T. G., and Dabney, S. M.: Dynamic replacement and loss of soil carbon on eroding cropland, Global Biogeochem. Сy., 13, 885-901, doi:10.1029/1999GB900061, 1999.

$\mathrm{Hu}$, Y., Fister, W., and Kuhn, N. J.: Temporal variation of SOC enrichment from interrill erosion over prolonged rainfall simulations, Agriculture, 3, 726-740, 2013a.

$\mathrm{Hu}$, Y., Fister, W., Rüegg, H.-R., Kinnell, P. A., and Kuhn, N. J.: The Use of Equivalent Quartz Size and Settling Tube Apparatus to Fractionate Soil Aggregates by Settling Velocity, Geomorphol. Tech. Online Ed. Br. Soc. Geomorphol., Section 1, 2013 b.

Iserloh, T., Fister, W., Seeger, M., Willger, H., and Ries, J. B.: A small portable rainfall simulator for reproducible experiments on soil erosion, Soil Tillage Res., 124, 131-137, doi:10.1016/j.still.2012.05.016, 2012.

Iserloh, T., Ries, J. B., Arnáez, J., Boix-Fayos, C., Butzen, V., Cerdà, A., Echeverría, M. T., Fernández-Gálvez, J., Fister, W., Geißler, C., Gómez, J. A., Gómez-Macpherson, H., Kuhn, N. J., Lázaro, R., León, F. J., Martínez-Mena, M., Martínez-Murillo, J. F., Marzen, M., Mingorance, M. D., Ortigosa, L., Peters, P., Regüés, D., Ruiz-Sinoga, J. D., Scholten, T., Seeger, M., SoléBenet, A., Wengel, R., and Wirtz, S.: European small portable rainfall simulators: A comparison of rainfall characteristics, Catena, 110, 100-112, doi:10.1016/j.catena.2013.05.013, 2013.

Jacinthe, P., Lal, R., and Kimble, J.: Carbon dioxide evolution in runoff from simulated rainfall on long-term no-till and plowed soils in southwestern Ohio, Soil Tillage Res., 66, 23-33, 2002.

Jacinthe, P., Lal, R., Owens, L. B., and Hothem, D. L.: Transport of labile carbon in runoff as affected by land use and rainfall characteristics, Soil Tillage Res., 77, 111-123, doi:10.1016/j.still.2003.11.004, 2004.

Kaiser, M., Berhe, A. A., Sommer, M., and Kleber, M.: Application of ultrasound to disperse soil aggregates of high mechanical stability, J. Plant Nutr. Soil Sci., 175, 521-526, doi:10.1002/jpln.201200077, 2012.

Kinnell, P. I. A.: Particle travel distances and bed and sediment compositions associated with rain-impacted flows, Earth Surf. Proc. Land., 26, 749-758, doi:10.1002/esp.221, 2001.

Kinnell, P. I. A.: Raindrop-impact-induced erosion processes and prediction: a review, Hydrol. Process., 19, 2815-2844, doi:10.1002/hyp.5788, 2005.

Kinnell, P. I. A. and McLachlan, C.: An injection barrel for the top entry sedimentation tube, Technical Memorandum, 43/1988, CSIRO Division soils, Australia, 1988.

Kuhn, N., Bryan, R., and Navar, J.: Seal formation and interrill erosion on a smectite-rich Kastanozem from NE-Mexico, CATENA, 52, 149-169, doi:10.1016/S0341-8162(02)00091-7, 2003.

Kuhn, N. J.: Erodibility of soil and organic matter: independence of organic matter resistance to interrill erosion, Earth Surf. Proc. Land., 32, 794-802, doi:10.1002/esp.1486, 2007.

Kuhn, N. J.: Assessing lateral organic Carbon movement in small agricultural catchments, Publ. Zur Jahrestag. Schweiz. Geomorphol. Ges., edited by: Graf, C., 29, 151-164, 2013.

Kuhn, N. J., Hoffmann, T., Schwanghart, W., and Dotterweich, M.: Agricultural soil erosion and global carbon cycle: controversy over?, Earth Surf. Proc. Land., 34, 1033-1038, doi:10.1002/esp.1796, 2009.

Lal, R.: Soil erosion and the global carbon budget, Environ. Int., 29, 437-450, doi:10.1016/S0160-4120(02)00192-7, 2003.

Lal, R. and Pimentel, D.: Soil erosion a carbon sink or source?, Science, 319, 1040-1041, 2008.

Loch, R. J.: Settling velocity - a new approach to assessing soil and sediment properties, Comput. Electron. Agric., 31, 305-316, 2001.

MeteoSwiss: Monthly total precipitation during April, May, and June at Station Arisdorf near Möhlin from 1985 to 2012, 2013.

Mora, J. L., Guerra, J. A., Armas, C. M., Rodriguez-Rodriguez, A., Arbelo, C. D., and Notario, J. S.: Mineralization rate of eroded organic $\mathrm{C}$ in andosols of the Canary Islands, Sci. Total Environ., 378, 143-146, doi:10.1016/j.scitotenv.2007.01.040, 2007.

Morgan, R. P. C., Quinton, J. N., Smith, R. E., Govers, G., Poesen, J. W. A., Auerswald, K., Chisci, G., Torri, D., and Styczen, M. E.: The European Soil Erosion Model (EUROSEM): a dynamic approach for predicting sediment transport from fields and small catchments, Earth Surf. Proc. Land., 23, 527-544, 1998.

Nadeu, E., Berhe, A. A., de Vente, J., and Boix-Fayos, C.: Erosion, deposition and replacement of soil organic carbon in Mediterranean catchments: a geomorphological, isotopic and land use change approach, Biogeosciences, 9, 1099-1111, doi:10.5194/bg-9-1099-2012, 2012.

Nimmo, J. R. and Perkins, K. S.: Aggregate stability and size distribution, in Soil Science Society of America, edited by: Dane, J. H., Topp, G. C., 4, 317-328, Madison, Wisconsin, 2002.

Orchard, V. A. and Cook, F. J.: Relationship between soil respiration and soil moisture, Soil Biol. Biochem., 15, 447-453, 1983.

Polyakov, V. O. and Lal, R.: Soil organic matter and CO2 emission as affected by water erosion on field runoff plots, Geoderma, 143, 216-222, doi:10.1016/j.geoderma.2007.11.005, 2008.

Quinton, J. N., Govers, G., Van Oost, K., and Bardgett, R. D.: The impact of agricultural soil erosion on biogeochemical cycling, Nat. Geosci., 3, 311-314, doi:10.1038/ngeo838, 2010.

Robertson, G. P., Wedin, D., Groffmann, P. M., Blair, J. M., Holland, E. A., Nadelhoffer, K. J., and Harris, D.: Soil carbon and nitrogen availability - Nitrogen mineralization, nitrification, and soil respiration potentials, in Standard Soil Method for Longterm Ecological Research, edited by: Robertson, G. P., Coleman, D. C., Bledsoe, C. S., Sollins, P., Oxford University Press, Oxford, 1999.

Rubey, W. W.: Settling velocities of gravel, sand, and silt particles, Am. J. Sci., 225, 325-338, 1933.

Sartori, M.: The quaternary climate in loess sediments, Diss. Naturwissenschaften ETH Zürich, Nr. 13570, available at: http:// e-collection.library.ethz.ch/view/eth:23643 (last access: 23 January 2014), 2000.

Schiettecatte, W., Gabriels, D., Cornelis, W. M., and Hofman, G.: Enrichment of organic carbon in sediment transport by interrill and rill erosion processes, Soil. Sci. Soc. Am. J., 72, 50-55, 2008.

Six, J., Conant, R. T., Paul, E. A., and Paustian, K.: Stabilization mechanisms of soil organic matter: Implications for C-saturation of soils, Plant. Soil., 241, 155-176, 2002.

Stallard, R. F.: Terrestrial sedimentation and the carbon cycle: Coupling weathering and erosion to carbon burial, Global Biogeochem. Cy., 12, 231-257, 1998. 
Starr, G. C., Lal, R., Malone, R., Hothem, D., Owens, L., and Kimble, J.: Modeling soil carbon transported by water erosion processes, Land Degrad. Dev., 11, 83-91, 2000.

Tisdall, J. M. and Oades, J. M.: Organic matter and water-stable aggregates in soils, J. Soil Sci., 33, 141-163, 1982.

Van Hemelryck, H., Fiener, P., Van Oost, K., Govers, G., and Merckx, R.: The effect of soil redistribution on soil organic carbon: an experimental study, Biogeosciences, 7, 3971-3986, doi:10.5194/bg-7-3971-2010, 2010.

Van Hemelryck, H., Govers, G., Van Oost, K., and Merckx, R.: Evaluating the impact of soil redistribution on the in situ mineralization of soil organic carbon, Earth Surf. Proc. Land., 36, 427-438, doi:10.1002/esp.2055, 2011.

Van Oost, K., Beuselinck, L., Hairsine, P. B., and Govers, G.: Spatial evaluation of a multi-class sediment transport and deposition model, Earth Surf. Proc. Land., 29, 1027-1044, doi:10.1002/esp.1089, 2004.

Van Oost, K., Quine, T. A., Govers, G., De Gryze, S., Six, J., Harden, J. W., Ritchie, J. C., McCarty, G. W., Heckrath, G., Kosmas, C., Giraldez, J. V., da Silva, J. R. M., and Merckx, R.: The Impact of Agricultural Soil Erosion on the Global Carbon Cycle, Science, 318, 626-629, doi:10.1126/science.1145724, 2007.

Van Oost, K., Verstraeten, G., Doetterl, S., Notebaert, B., Wiaux, F., Broothaerts, N., and Six, J.: Legacy of human-induced C erosion and burial on soil-atmosphere C exchange, Proc. Natl. Acad. Sci., 109, 19492-19497, doi:10.1073/pnas.1211162109, 2012.
Walling, D. E.: Erosion and sediment yield research-some recent perspectives, J. Hydrol., 100, 113-141, 1988.

Walling, D. E. and Webb, B. W.: Erosion and sediment yield: a global overview, in Erosion and Sediment Yield: Global and Regional Perspectives, 3-19, IAHS Press, Institute of Hydrology, Wallingford, Oxfordshire, Exeter, UK, 1996.

Wang, X., Gao, H., Tullberg, J. N., Li, H., Kuhn, N. J., Mchugh, A., and Li, Y.: Traffic and tillage effects on runoff and soil loss on the Loess Plateau of northern China, Soil Res., 46, 667-675, 2008.

Wang, Z., Govers, G., Steegen, A., Clymans, W., Van den Putte, A., Langhans, C., Merckx, R., and Van Oost, K.: Catchmentscale carbon redistribution and delivery by water erosion in an intensively cultivated area, Geomorphology, 124, 65-74, doi:10.1016/j.geomorph.2010.08.010, 2010.

$\mathrm{Wu}, \mathrm{W}$. and Wang, S. S.: Formulas for sediment porosity and settling velocity, J. Hydraul. Eng., 132, 858-862, 2006.

$\mathrm{Xu}$, L., Baldocchi, D. D., and Tang, J.: How soil moisture, rain pulses, and growth alter the response of ecosystem respiration to temperature, Global Biogeochem. Cy., 18, 1-10, doi:10.1029/2004GB002281, 2004.

Zibilske, L. M.: Carbon mineralization, in Methods of Soil Analysis, Part 2, Microbiogical and Biochemical Properties, Vol. SSSA Book Series, 5, Madison, Wisconsin, USA, 835-863, 1994. 